\title{
EXAMINING THE RELATIONSHIP BETWEEN FINANCIAL DEVELOPMENT AND INTERNATIONAL TRADE IN CROATIA
}

Vlatka Bilas, Mile Bosnjak, Ivan Novak

\section{Abstract}

This paper examines the relationship between financial development and international trade in Croatia over the period from the first quarter of 1997 and the last quarter of 2015. The autoregressive distributed lag (ARDL) bounds testing approach to cointegration is applied to examine the long-run and short-run relationships among the series. The research hypothesis is accepted and the relationship between financial development and international trade in Croatia is established and confirmed. The research results reveal unidirectional Granger causality from financial development to international trade at the 10\% significance level, and negative long-run and the positive short-run relationships between financial developments and international trade in Croatia.

Keywords: financial development, international trade, Croatia

JEL classification: $F 14, G 1, C 01$

\section{INTRODUCTION}

International trade theories do not take the role of finance into consideration as a source of comparative advantage. A vast empirical literature in finance has indicated the importance of financial development for industries that need more external finance. Nevertheless, the effects of finance in international trade theory are still unexplored (Ju and Wei, 2011). The complexity of the financial environment and economic history are different for different countries, so the relationship between international trade and financial development should be examined on a single country basis or on a group of similar countries. Financial liberalization in Croatia has resulted in an increase in financial inflow from abroad. According to Croatian National Bank (CNB) data on Foreign Direct Investment (FDI) from the year 1993 on, the greatest portion of FDI in Croatia has been directed towards the financial intermediation sector (mainly foreign

\section{Vlatka Bilas, PhD \\ Associate professor \\ Faculty of Economics and Business \\ University of Zagreb, Croatia \\ E-mail:vbilas@efzg.hr \\ Mile Bosnjak, $\mathrm{PhD}$ \\ Faculty of Economics and Business \\ University of Zagreb, Croatia \\ E-mail: mailto:mile.bosnjak76@gmail.com}

Ivan Novak, $\mathrm{PhD}$

Faculty of Economics and Business

University of Zagreb, Croatia

E-mail: inovak@efzg.hr 
owned credit institutions). In Croatia, the banking system has been rapidly turned into one of the most dynamic sectors of the Croatian economy. At the same time, trade liberalization has been prominent in Croatia. International trade liberalization in Croatia has been achieved through several phases, namely membership in the World Trade Organization (WTO), the Stabilization and Association Agreement (SAA) with the European Union (EU), the negotiation process for EU membership (Goldner Lang and Perišin, 2011) and eventually full membership in the EU. The direct linkages between two of the aforementioned phenomena have not been yet examined in Croatia. However, Bilas and Bošnjak (2015) provided empirical evidence for statistically significant long-run and short-run effects of banking loans to private individual growth rate on personal consumption growth rate in Croatia. Using a cointegration approach, Bilas and Bošnjak (2015) found empirical evidence for debtfinanced consumption in Croatia for a period of fifteen years. Bošnjak, Novak and Šverko (2013) empirically confirmed the personal consumption effects on import demand in Croatia. The present research on whether financial development in Croatia is related to Croatian international trade brings a missing puzzle to the previous related research. In this paper the research hypothesis can be stated thus: there is a relationship between financial development and international trade in Croatia.

The rest of the paper is organized as follows: Section 2 briefly summarizes the existing literature on the research topic. Section 3 presents research data and methodology, while Section 4 provides empirical results and a discussion. The final section provides an overview of the main findings of the research and conclusions.

\section{BRIEF LITERATURE OVERVIEW}

The relationship between financial development and international trade has been examined from the perspective of economies of scale, and the results showed that international trade has been affected by the financial sector (Beck 2003; Svaleryd and Vlachos, 2005). As a potential explanation of the influence from financial development, Beck (2003) as well as Svaleryd and Vlachos (2005), suggested that a more developed financial sector may channel more savings to the private sector, which may facilitate enterprises to the use of external financing and eventually help firms overcome liquidity constraints. Kletzer and Bardhan (1987) showed that countries with a relatively well-developed financial sector have a comparative advantage in industries and sectors that rely on external finance. A developed domestic financial sector is also helpful in increasing the foreign firm's borrowing to broaden their innovative activities in the domestic economy (Omran and Bolbol 2003). Following Rajan and Zingales (1998), financial development helps firms to avoid moral hazard and adverse selection problems and to enhance export growth by using external financing. Manova (2013) points out that more developed financial markets support industries with a higher dependence on external finance in exporting more. Amiti and Weinstein (2011) confirmed the link between access to external finance and international trade at the firm level. Kim, Lin and Suen (2010) examined the influence of international trade on financial development. The research results point out the importance of trade openness in determining levels of financial development. Furthermore, the results indicate different long-run and short-run effects of trade, and that the relationship between international trade and financial development may be country-specific. Samba and Yan (2009) found similar results for selected East Asian Countries, pointing out that international trade leads to financial development in most of the countries in the sample. Susanto et al. (2011) found the positive effect of financial development on bilateral trade flows and that the effect is more prominent in the manufacturing sector, with relatively large economies of scale. Furthermore, according to the results of their research, an export from developing countries is more affected by financial development than an export from developed countries. Demir and Dahi (2011) indicate that a well-developed financial sector has positive impacts on exports with higher value added and on exports of manufactured goods that depend on external finance. Awojobi (2013) examined the relationship in Greece and found unidirectional causality from trade openness to financial development. Kar et al. (2013) examined the relationship in Turkey for the period of 1989-2007 and found a unidirectional relationship from financial development to international trade. Gries, Kraft and Meierrieks (2009) examined the relationship among financial development, international trade and economic development and found the evidence indicates that financial deepening and trade openness have swayed economic development rather marginally. According to Goksel (2012), there are negative effects from financial constraints in a country on its exporting performance and the differences in financial structures between countries affect bilateral trade. Empirical findings in his study show that financial development encourages the amounts of countries' exports, since firms need credits to cover their costs. Therefore, trade volume between 
countries that have relatively healthier financial markets will be higher. Following Feng and Lin (2013), export-oriented firms face larger fixed costs in production and rely more on external finance. Therefore, worsening financial conditions affect export-oriented firms more adversely than domestic-oriented ones. Following Mishkin (2009), international trade will stimulate financial development. An economy with more developed financial markets and institutions tends to have a significantly higher economic growth rate (Shahbaz and Rahman 2012). Chimobi (2010) examined the causal relationship among financial development, trade openness and economic growth in Nigeria using data from 1970-2005; the Johansen multivariate approach to cointegration was applied, but found no cointegrating relations between growth, trade openness and financial development. Shaheen et al. (2011) also confirmed a long-run relationship between financial development, international trade and economic growth in the case of Pakistan. Korhan et al. (2015), based on the empirical results for Pakistan, suggests that better financial system will promote international trade and consequently economic growth. Following Korhan et al. (2015), financial development may represent a certain degree of comparative advantage for at least those industries that have a higher dependence on external financing. Such industries are likely to have higher shares of exports and obtain more trade benefits in countries that have higher levels of financial development. However, there is another potential linkage between financial development and international trade. The interrelationship between financial development and international trade may exist through the linkage between debt-finance consumption and imports. Strong growth in domestic demand financed by the inflow of foreign loans and real appreciation of domestic currencies stimulated the consumption of mainly imported goods and resulted in current account deficit in European transition countries (Aristovnik 2008; Zakharova 2008; Bakker and Gulde 2010; Obadić et al., 2014). Kiendrebeogo (2012) examined the linkage between financial development and international trade in developed and developing countries for the period of 1961-2010. The research results indicate a bidirectional relationship between financial development and international trade. Furthermore, the results indicate that due to different levels of economic development the causality varies between developed and developing countries. Conclusively, the existing literature does not point to a consistent conclusion with regard to the relationship between financial development and international trade.

Following the last global financial crisis, the importance of the relationship between finance and international trade has been highlighted (Manova and Foley, 2015; Contessi and de Nicola 2012). We want to contribute to this growing literature by testing whether financial development and international trade in Croatia are interconnected.

\section{RESEARCH DATA AND METHODOLOGY}

Following Gries, Kraft and Meierrieks (2009), Kiendrebeogo (2012) and Kar, Nazlıoglu and Agır (2013), the relationship between financial development and international trade in Croatia is examined using equation (1).

$$
T R A D E_{t}=f\left(L P S_{t}, G R W_{t}, F X_{t}\right)
$$

The variable TRADE in equation (1) is the sum of exports and imports of goods and services measured as a percentage of gross domestic products (GDP). LPS denotes loans to the private sector by credit institutions as a percentage of GDP. GRW represents the quarterly GDP growth rate (comparison with previous quarter) and $F X$ represents the official exchange rate (EUR/HRK period average). Both are taken as control variables in the equation.

The quarterly data representing international trade and GDP growth in the model are taken from the Croatian Bureau of Statistics and the data representing LPS and FX are taken from the Croatian National Bank. The period of the study encompasses the data between the first quarter of 1997 and the last quarter of 2015. Graphs related to the series used in the model are shown in Figure 1.

Following Figure 1 and the fact that we observed a quarterly data series, the variables in the model are seasonally adjusted.

First, to avoid spurious results it is essential to check each time series for stationarity, the results of which are the baseline for the methodology selection. The stationarity properties for each time series are examined using unit-root tests. Itis well known that unit-root tests cannot easily distinguish between a unit root and close alternatives as originally noted by Elliott (1998). So, an ADF test (Dickey and Fuller 1979), PP test (Phillips and Perron 1988) and KPSS test (Kwiatkowski, Phillips, Schmidt and Shin 1992) are employed. The results are summarized in Table 1.

The unit-root test results in Table 1 indicate that the variables trade openness and loans to the private sector by credit institutions as a percentage of GDP are integrated at order one I(1) i.e. they are stationary in their first differences. Following unit root tests 
Figure 1: The graphs of variables used in the model

FX

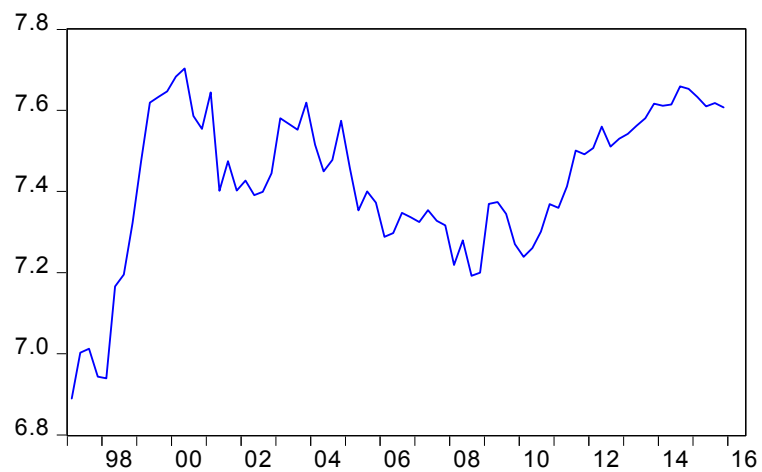

LPS

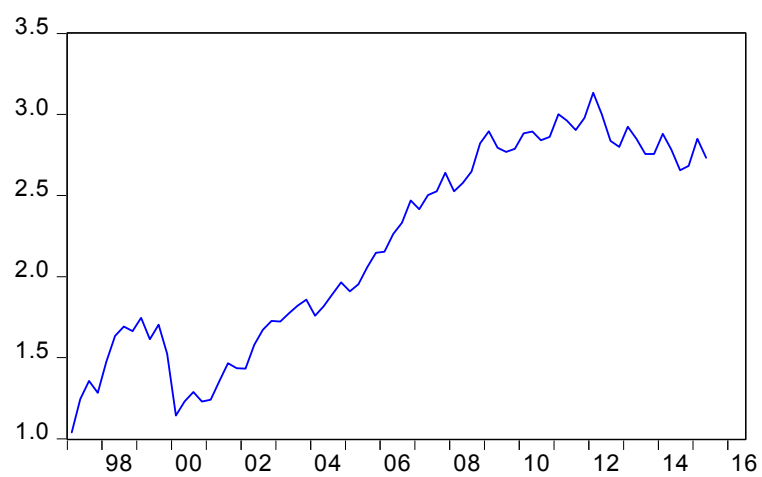

GRW

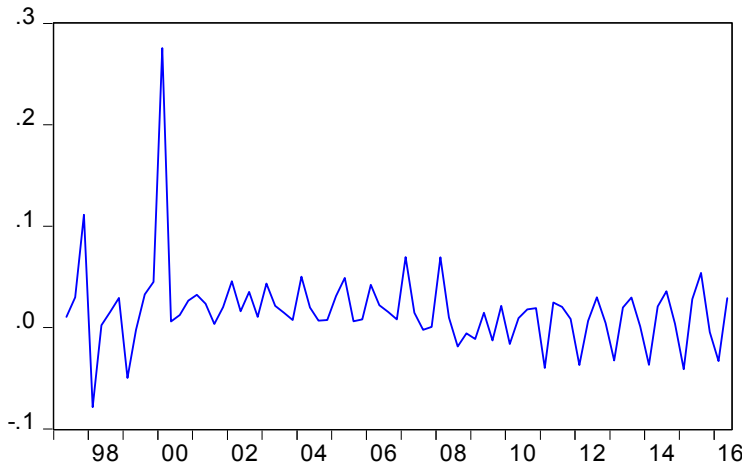

TRADE

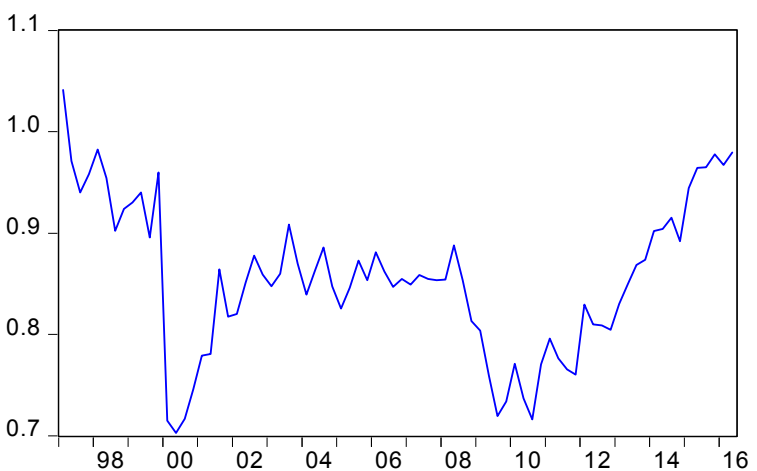

Source: Croatian Bureau of Statistics, Croatian National Bank

Table 1: Unit root test results

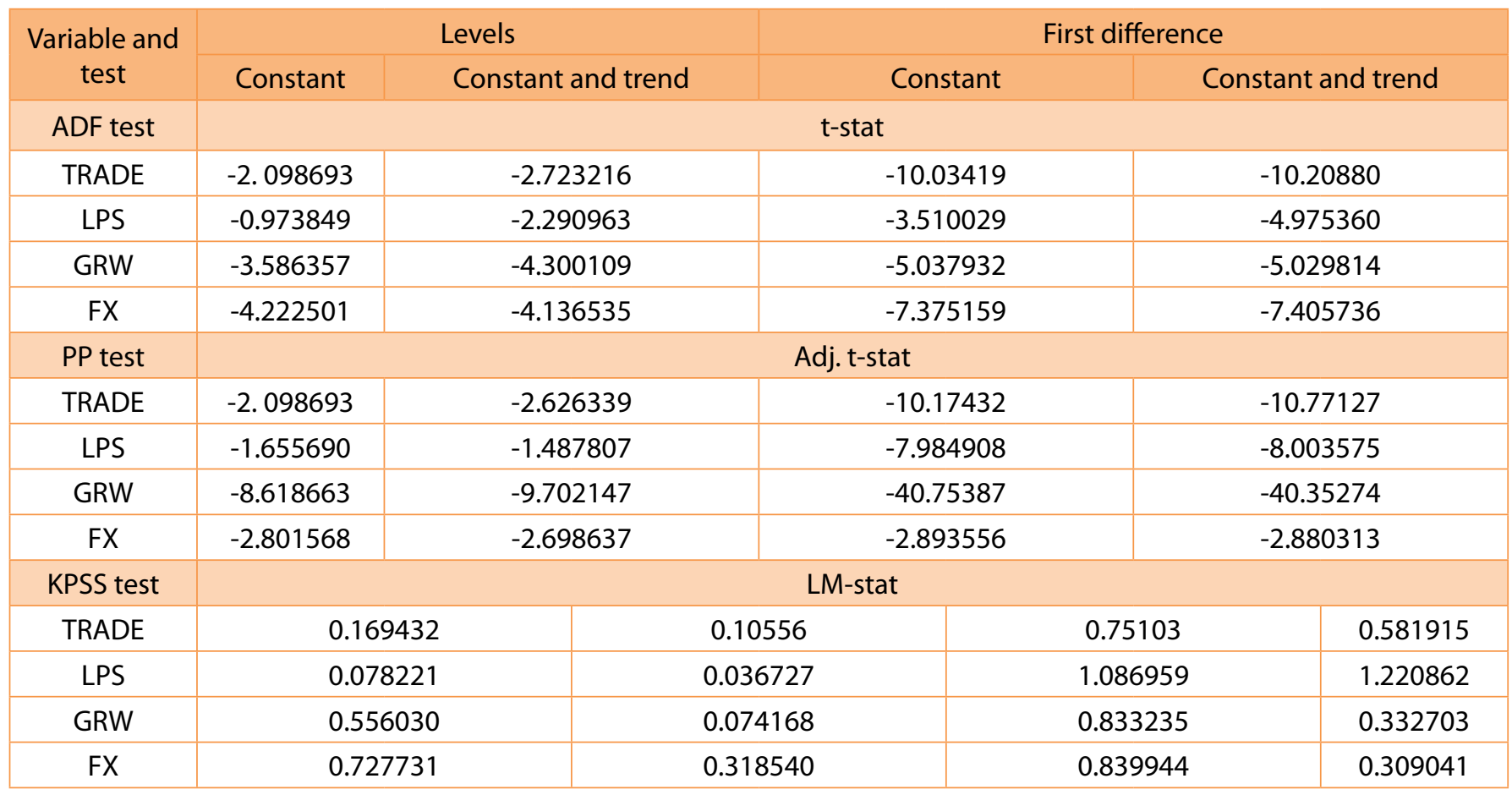

Source: Authors. 
Table 2: Testing for the existence of a level relationship among the variables in the ARDL model

\begin{tabular}{|c|c|c|c|c|}
\hline \multirow{2}{*}{ F-statistic } & $99 \%$ Upper Bound & $97.5 \%$ Upper Bound & $95 \%$ Upper Bound & $90 \%$ Upper Bound \\
\hline \multirow{2}{*}{8.826421} & 5.23 & 4.68 & 4.23 & 3.74 \\
\cline { 2 - 5 } & $99 \%$ Lower Bound & $97.5 \%$ Lower Bound & $95 \%$ Lower Bound & $90 \%$ Lower Bound \\
\cline { 2 - 5 } & 4.30 & 3.80 & 3.38 & 2.97 \\
\hline
\end{tabular}

Source: Authors.

results for the variables quarterly GDP growth rate and foreign exchange rate, these two variables are stationary at its levels. Mance et al. (2015) found the EUR/HRK foreign exchange rate stationary at this level as well. Taking into account the aforementioned unitroot tests results, to estimate the equation an autoregressive distributed lag (ARDL) modeling approach is used. The ARDL model introduced by Pesaran and Shin (1995) and extended by Pesaran, Shin and Smith (2001) deals with a single cointegration equation, making it simple to implement and interpret. The another advantage of ARDL approach and the main reason for it being employed in this paper is that it can be applied irrespective of whether the independent variables are I(0) or I(1). Furthermore, different variables can be assigned different lag-lengths as they enter the model. Following an ARDL approach, the bounds test for cointegration is performed and following the test results the long-run relationship and the associated error correction model are estimated. Bounds test results for cointegration are given in Table 2 .

The results in Table 2 show computed F-statistics, as well as the lower and upper bounds for the corresponding confidence interval. If the computed F-statistics falls below the lower bound, the null hypothesis of no long-run relationship can be accepted without needing to know whether the variables are I(0) or I(1), or fractionally integrated. In the case of the computed F-statistics being between these two bounds, the result is inconclusive and depends on whether the variables are I(0) or I(1), and the unit root tests on the variables may be performed. Since the computed F-statistic exceeds the upper bounds, the null hypothesis of no long-run relationship is rejected.

Since the model is being estimated on quarterly data, the maximum lags order in the baseline ARDL model is 4 and the trend is included ${ }^{1}$. The ARDL financial development and international trade equation in its general form is represented as follows:

1 The comparison of the information criteria (AIC - Akaike Information Criterion, SBC - Schwarz Bayesian Criterion and HQ Hannan-Quinn Criterion) showed that higher values of the information criterion achieve models that include a trend.

$$
\begin{gathered}
\Delta T R A D E_{t}=c_{0}+c_{1} \cdot t+\sum_{I=1}^{n} \alpha_{i} \cdot \Delta T R A D E_{t-i}+ \\
\sum_{I=1}^{n} \beta_{i} \cdot \Delta M_{t-i}+\sum_{I=1}^{n} \delta_{i} \cdot \Delta G R W_{t-i}+
\end{gathered}
$$$$
\sum_{I=1}^{n} \theta_{i} \cdot \Delta F X_{t-i}+\gamma_{1} \cdot T R A D E_{t-1}+\gamma_{2} \cdot \Delta M_{t-1}+
$$$$
\gamma_{3} \cdot \Delta G R W_{t-1}+\gamma_{4} \cdot \Delta F X_{t-1}+\varepsilon_{t}
$$

Wherere $c_{0}, c_{1}$ presents constant and trend, $y_{1}, y_{2}$, $y_{3}$ and $y_{4}$ are the long-run multipliers while $a_{i}, \beta_{i}, \delta_{i}$ and $\theta_{i}$ represent the short-run dynamic coefficients. Following the Akaike info criterion (AIC), ARDL $(1,2,4,4)$ model is selected. Eventually, since the long-run relationship is confirmed, Engle and Granger (1987) and Granger (1988) causality analyses are performed.

\section{RESULTS AND DISCUSSION}

The level relationship, i.e. the long-run $\operatorname{ARDL}(1,2$, 4 ,4) financial development and international trade equation, is presented in Table 3.

Following the results in Table 3, estimated long-run coefficients are generally statistically significant, with the exception of the EUR/HRK exchange rate (FX) that is not significant at a usually accepted significance level. The variables of interest together make a longrun equilibrium. According to the results in Table 3, the relationship between financial developments an international trade is negative; i.e., higher loans to the private sector by credit institutions as a percentage of GDP is correlated with lower trade openness in the long-run. Table 4 summarizes estimation results for the error correction equation form.

The estimation results in Table 4 show a statistically significant error correction. Furthermore, the error correction term is negative, as expected. The variables are strongly interrelated and form a long-run equilibrium. Furthermore, if the variables move from the equilibrium state they form together, the previous period disequilibrium will be corrected at a speed of $16 \%$. In 
Table 3: Estimated long-run coefficients of the $\operatorname{ARDL}(1,2,4,4)$ financial development and international trade equation

\begin{tabular}{|c|c|c|c|c|}
\hline \multicolumn{5}{|c|}{ Dependent variable: TRADE } \\
\hline Variable & Coefficient & Std. Error & T-Statistic & Prob. \\
\hline LPS & -0.474790 & 0.221706 & -2.141532 & 0.0036 \\
\hline GRW & -4.496218 & 2.208871 & -2.035527 & 0.0468 \\
\hline FX & -0.152383 & 0.319105 & 0.477533 & 0.6349 \\
\hline @TREND & 0.012700 & 0.006560 & 1.936005 & 0.0582 \\
\hline
\end{tabular}

Source: Authors.

Table 4: Error correction representation of the $\operatorname{ARDL}(1,2,4,4)$ financial development and international trade equation

\begin{tabular}{|c|c|c|c|c|}
\hline \multicolumn{5}{|c|}{ Dependent variable: $\triangle T$ RADE } \\
\hline Variable & Coefficient & Std. Error & T- Statistic & Prob. \\
\hline$\Delta \mathrm{LPS}$ & -0.035922 & 0.044023 & -0.815983 & 0.4182 \\
\hline$\Delta \mathrm{LPS}(-1)$ & 0.172412 & 0.044729 & 3.854567 & 0.0003 \\
\hline$\Delta \mathrm{FX}$ & -0.030509 & 0.042139 & -0.724002 & 0.4722 \\
\hline$\Delta \mathrm{FX}(-1)$ & -0.107516 & 0.041728 & -2.576571 & 0.0128 \\
\hline$\Delta \mathrm{FX}(-2)$ & 0.202648 & 0.040279 & 5.031109 & 0.0000 \\
\hline$\Delta \mathrm{FX}(-3)$ & 0.077266 & 0.042020 & 1.838780 & 0.0716 \\
\hline$\Delta \mathrm{GRW}$ & -0.692211 & 0.097001 & -7.136089 & 0.0000 \\
\hline$\Delta \mathrm{GRW}(-1)$ & 0.186339 & 0.160372 & 1.161918 & 0.2505 \\
\hline$\Delta G R W(-2)$ & 0.018167 & 0.116216 & 0.156325 & 0.8764 \\
\hline$\Delta \mathrm{GRW}(-3)$ & -0.152423 & 0.077336 & -1.970911 & 0.0540 \\
\hline C & 0.415561 & 0.093288 & 4.454606 & 0.0000 \\
\hline CointEq(-1) & -0.159966 & 0.035692 & -4.481802 & 0.0000 \\
\hline \multicolumn{5}{|c|}{ CointEq $=$ TRADE $-\left(-0.474790^{*}\right.$ LPS $\left.-0.1524^{*} \mathrm{FX}-4.4962^{*} \mathrm{GRW}+0.0127^{*} @ T R E N D\right)$} \\
\hline \multicolumn{3}{|c|}{ R-squared $=0.883514$} & \multicolumn{2}{|c|}{ Adjusted R-squared $=0.850546$} \\
\hline \multicolumn{3}{|c|}{ Log likelihood = 166.1991} & \multicolumn{2}{|c|}{ Akaike info criterion $=-4.353598$} \\
\hline \multicolumn{2}{|c|}{ Schwarz criterion $=-3.835545$} & & \multicolumn{2}{|c|}{ Hannan-Quinn criter $=-4.148069$} \\
\hline
\end{tabular}

Source: Authors.

other words, it will take about year and a half to retain their long-run equilibrium steady state. Holding the desired significance level at 5\%, the results in Table 4 indicate that change in loans to private sector measured as a percentage of GDP is significant with lag one. The change in EUR/HRK exchange rate is significant with lag one and lag two while the change in percentage of quarterly GDP growth rate is significant without lag. However, in comparison to the estimated results for the long run we found the opposite sign for the short-run relationship between international trade and financial development and for the international trade and EUR/HRK foreign exchange rate relationship. Furthermore, the EUR/HRK exchange rate is not a significant variable in the long-run. About $88.35 \%$ of the variation in Croatian international trade can be explained by variations in loans to the private sector by credit institutions as percentage of GDP, quarterly GDP growth rate (comparison with previous quarter) and the official EUR/HRK exchange rate. Afterwards, model assumptions were tested. Residuals properties for the estimated model are presented in Table 5.

Table 5: Residuals normality diagnostics of the ARDL $(1,2,4,4)$ financial development and international trade equation

\begin{tabular}{|l|l|}
\hline Mean $=-8.06 e-17$ & Median $=0.001620$ \\
\hline Maximum $=0.057744$ & Minimum $=-0.071048$ \\
\hline Std. Dev. $=0.021921$ & Skewness $=-0.282381$ \\
\hline Kurtosis $=3.825828$ & Jarque-Bera $=2.877723$ \\
\hline
\end{tabular}

Source: Authors. 
Following Table 5, residuals are normally distributed, and therefore the T- statistic is relevant to determine the significance of the independent variables in the model. A correlogram shows no autocorrelation or partial correlations up to leg twenty eight, and the heteroskedasticity test indicates constant variance. Unbiased and efficient estimates were obtained. Conclusively, the diagnostic tests suggest that the model is adequately estimated and that the conclusions of the model are reliable.

Since cointegration is confirmed in the estimated model, we tested Granger causality among the variables observed. Granger causality test results are presented in Table 6.

Granger causality test results in Table 6 point out on existing unidirectional Granger causality from financial development to international trade at a significance level of $10 \%$. Holding the significance level at $10 \%$, bidirectional Granger causality has been found between financial development and economic growth and unidirectional Granger causality from EUR/HRK exchange rate to international trade.

Hence the relationship between financial development and international trade in Croatia exists. An increase of loans to the private sector by credit institutions as a percentage of GDP is positively correlated with an increase in trade openness in the short-run but in the long run the relationship is negative. Bilas and Bošnjak (2015) established and confirmed longrun and short-run effects of banking loans to private individuals' growth rate on the personal consumption growth rate in Croatia. If it is the consumption of mainly imported goods as reported by Obadić et al. (2014) for example, it might increase the trade in the short-run. Furthermore, the Granger causality test results in Table 6 indicate the relationship between financial development and economic growth. If it is the case that influence from financial development to economic growth is more prominent than influence from financial development to international trade in the long run the final result will be negative.

Furthermore, Croatia is a highly indebted country with regard to public debt (Sopek 2011) and foreign debt (Rahman 2011). Intuitively, the effect of financial development might be more prominent on the demand side, i.e. imports in Croatia. Additional effort might be needed to establish a more effective relationship between the Croatian financial system and the production side of the Croatian economy to enhance export growth by using external financing.

\section{CONCLUDING REMARKS}

There are several conclusions that can be drawn from the research presented in this paper. First, the existing literature points to various channels for the relationship between financial development and international trade. The relationship might be unidirectional and bidirectional. Furthermore, the relationship between financial developments to international trade might be import-dominant or export-dominant. Second, we found a strong cointegration between financial development and international trade in Croatia and accepted our initially stated research hypothesis. The research results reveal the negative sign of the relationship between financial development and international trade in the long-run, while the

Table 6: Granger causality test results for the observed variables with lag four

\begin{tabular}{|c|c|c|c|}
\hline Null Hypothesis & Obs & F-Statistic & Prob. \\
\hline LPS does not Granger Cause TRADE & 70 & 2.23690 & 0.0754 \\
\hline TRADE does not Granger Cause LPS & 70 & 0.25153 & 0.9077 \\
\hline GRW does not Granger Cause TRADE & 73 & 0.52535 & 0.7174 \\
\hline TRADE does not Granger Cause GRW & 73 & 1.33956 & 0.2650 \\
\hline FX does not Granger Cause TRADE & 72 & 2.11264 & 0.0893 \\
\hline TRADE does not Granger Cause FX & 72 & 1.64547 & 0.1740 \\
\hline GRW does not Granger Cause LPS & 69 & 2.14147 & 0.0867 \\
\hline LPS does not Granger Cause GRW & 69 & 6.49055 & 0.0002 \\
\hline FX does not Granger Cause LPS & 70 & 6.05545 & 0.0004 \\
\hline LPS does not Granger Cause FX & 70 & 0.22161 & 0.9254 \\
\hline FX does not Granger Cause GRW & 71 & 0.70411 & 0.5921 \\
\hline GRWdoes not Granger Cause FX & 71 & 0.36650 & 0.8316 \\
\hline
\end{tabular}

Source: Authors. 
relationship in the short-run is positive. The relationship might be import-dominant due to consumption of mainly imported goods. International trade, real GDP growth and loans to the private sector by credit institutions as a percentage of GDP are closely related in Croatia in the long-run, while the EUR/HRK exchange rate obtained its significance only in the short-run. The effects of the financial system and its development on international trade in Croatia might be more prominent on the demand side, meaning there might be space to take more advantage of financial development in Croatia. More effort should be directed towards establishing a closer relationship between the corporate and financial sectors in Croatia. Financial system development in Croatia might be redirected toward exporting companies to facilitate enterprises with the use of external financing and eventually help firms overcome possible liquidity constraints.

\section{REFERENCES}

Amiti, M. and Weinstein, D. E. 2011. Exports and Financial Shocks. The Quarterly Journal of Economics 126 (4): 1841-1877.

Aristovnik, A. 2008. Short-Term Determinants of Current Account Deficits: Evidence from Eastern Europe and the Former Soviet Union. Eastern European Economics 46 (1): 24-42.

Awojobi, O. 2013. Does Trade Openness and Financial Liberalization Foster Growth: An Empirical Study of Greek Economy. International Journal of Social Economics 40 (6): 537-555.

Bakker, B. B. and Gulde, A. M. 2010. The Credit Boom in the EU New Member States: Bad Luck or Bad Policies? International Monetary Fund Working Paper 10/130.

Beck, T. 2003. Financial dependence and international trade: is there a link. Review of International Economics 11: 296-316.

Bilas, V. and Bošnjak, M. 2015. Examining the relationship between banking loans to private individuals growth rate and personal consumption growth rate in Croatia the cointegration approach. Notitia - časopis za održivi razvoj 1: 19-26.

Bošnjak, M., Novak, I. and Šverko, I. 2013. Macroeconomic Shocks Influence on NPL Level in Small Open Economy: Example of Croatia, paper presented at the conference. The Clute Institute International Academic Conference. Las Vegas, September.

Chimobi, O. P. 2010. The causal relationship among financial development, trade openness and economic growth in Nigeria. International Journal of Economics and Finance 2 (2): 138-147.
Contessi, S. and de Nicola, F. 2012. What do we know about the relationship between access to finance and international trade. Federal Reserve Bank of St. Louis Working Papers 2012-054B, St. Louis: Federal Reserve Bank of St. Louis.

Demir, F. and Dahi, O. S. 2011. Asymmetric effects of financial development on South-South and South-North trade: Panel data evidence from emerging markets. Journal of Development Economics 94: 139-149.

Dickey, D. A. and Wayne A. F. 1979. Distribution of the Estimators for Autoregressive Time Series with a Unit Root. Journal of the American Statistical Association 74 (366): 427-431.

Elliott, G. 1998. On the Robustness of Cointegration Methods When Regressors Almost Have Unit Roots. Econometrica 66 (1): 149-158.

Engle, R. F. and Clive W. J. G. 1987. Cointegration and Error Correction: Representation, Estimation, and Testing. Econometrica 55 (2): 251-276.

Feng, L. and Lin, C. Y. 2013. Financial shocks and exports. International Review of Economics and Finance 26: 39-55.

Goksel, T. 2012. Financial constraints and international trade patterns. Economic Modelling 29 (6): 2222-2225.

Goldner-Lang. I. and Perišin, T. 2011. Postupna liberalizacija kretanja roba i ljudi u Hrvatskoj i Makedoniji - prije i nakon članstva u EU. Zbornik Pravnog fakulteta u Zagrebu 61 (2): 613-642.

Granger, C. W. J. 1988. Some recent developments in the concept of causality. Journal of Econometrics 39 (1-2): 199-211.

Gries, T., Kraft, M. and Meierrieks, D. 2009. Linkages between financial deepening, trade openness, and economic development: Causality evidence from Sub-Saharan Africa. World Development 37 (12):1849-1860.

Ju, J. and Shang-Jin, W. 2011. When is quality of financial system a source of comparative advantage?. Journal of International Economics 84 (2): 178-187.

Kar, M., Saaban, N. and Huseyin, A. 2013. Trade Openness, Financial Development, and Economic Growth in Turkey: Linear and Nonlinear Causality Analysis. Paper presented at the International Conference on Eurasian Economies, St. Petersburg, September.

Kiendrebeogo, Y. 2012. Understanding the Causal Links between Financial Development and International Trade. Series Etudes et Documents Du Cerdi, No. 34, Clermont Ferrand: CERDI.

Kim, D. H., Lin, S. C. and Suen, Y. B. 2010. Dynamic effects of trade openness on financial development. Economic Modelling 27 (1): 254-261.

Kletzer, K. and Pranab. B. 1987. Credit markets and patterns of international trade. Journal of Development Economics 27 (1-2): 57-70. 
Korhan K. G., Amina, M. Y. and Taspinara, N. 2015. The Relationship among International Trade, Financial Development and Economic Growth: The Case of Pakistan. Procedia Economics and Finance 25: 489 - 496

Kwiatkowski, D., Phillips, P. C. B., Schmidt, P. and Yongcheol S. 1992. Testing the null hypothesis stationarity against the alternative of a unit root: How sure are we that economic time series have a unit root? Journal of Econometrics 54: 159-178.

Mance, D., Žiković, S. and Mance, D. 2015. Econometric Analysis of Croatia's Proclaimed Foreign Exchange Rate. South East European Journal of Economics and Business 10 (1): 7-17.

Manova, K. 2013. Credit Constraints, Heterogeneous Firms, and International Trade. Review of Economic Studies 80: 711-744.

Manova, K. and Fritz, F. C. 2015. International trade, multinational activity, and corporate finance. Annual Review of Economics 7: 119-146.

Mishkin, F. S. 2009. Globalization and financial development. Journal of Development Economics 89 (2): 164-169.

Obadić, A., Globan, T. and Nadoveza, O. 2014. Contradicting the Twin Deficits Hypothesis: The Role of Tax Revenues Composition. Panoeconomicus 6: 653-667.

Omran, M. and Bolbol, A. 2003. Foreign direct investment, financial development, and economic growth: evidence from the Arab countries. Review of Middle East Economics and Finance. 1 (3): 233-251.

Pesaran, H. and Shin, Y. 1995. An Autoregressive Distributed Lag Modelling Approach to Cointegration Analysis. Paper presented at the conference The Ragner Frisch Centennial Symposium, Cambridge.
Pesaran, H., Shin, Y. and Smith, R- J. 2001. Bounds Testing Approaches to the Analysis of Level Relationships. Journal of Applied Econometrics 16 (3): 289-326.

Phillips, P. C. B. and Perron, P. 1988. Testing for a Unit Root in Time Series Regression. Biometrika 75 (2): 335-346.

Rajan, R. G. and Zingales, L. 1998. Financial development and growth. American Economic Review 88 (3): 559-586.

Samba, M. C. and Yan, Y. 2009. Financial Development and International Trade in Manufactures: An Evaluation of the Relation in Some Selected Asian Countries. International Journal of Business and Management 4 (12): 52-69.

Shahbaz, M. and Rahman, M. M. 2012. The dynamic of financial development, imports, foreign direct investment and economic growth: cointegration and causality analysis in Pakistan. Global Business Review 13 (2): 201-219.

Shaheen, S., Awan, M. S., Waqas, M. and Aslam, M. A. 2011. Financial development, international trade and economic growth: empirical evidence from Pakistan. Romanian Journal of Fiscal Policy 2 (2): 11-19.

Susanto, D., C., Rosson. P. and Costa, R. 2011. Financial Development and International Trade: Regional and Sectoral Analysis. Agricultural \& Applied Economics Association 2011 AAEA \& NAREA Joint Annual Meeting, Pittsburgh, Pennsylvania.

Svaleryd, H. and Vlachos, V. 2005. Financial markets, the pattern of industrial specialization and comparative advantage: evidence from OECD countries. European Economic Review 49 (1): 113-144.

Zakharova, D. 2008. One-Size-Fits-One: Tailor-Made Fiscal Responses to Capital Flows. International Monetary Fund. 